\title{
UPAYA MENINGKATKAN HASIL BELAJAR PKn DENGAN METODE THINK PAIR SHARE (TPS) PADA SISWA KELAS 7 D SMP NEGERI 1 JAPAH KECAMATAN JAPAH KABUPATEN BLORA SEMESTER GENAP TAHUN PELAJARAN 2012/2013
}

\author{
Nani Mediatati \\ Program Studi S1 PPKn \\ FKIP Universitas Kristen Satya Wacana \\ Sayudi Riawan \\ Alumni Program Studi S1 PPKn \\ FKIP Universitas Kristen Satya Wacana
}

\begin{abstract}
ABSTRAK
Dalam pembelajaran PKn guru kelas 7 D SMP Negeri 1 Japah sering menggunakan metode ceramah yang lebih terpusat pada guru sehingga guru yang lebih aktif dan siswanya bersifat pasif. Hal ini mengakibatkan hasil belajar PKn siswa kelas 7 D SMP Negeri 1 Japah banyak yang belum mencapai KKM e"72. Dari data hasil belajar siswa dalam pembelajaran PKn materi "Sikap Positif Terhadap Perlindungan dan Penegakan Hak Asasi Manusia"(Pra siklus) diketemukan 25 siswa (67,57\%) belum tuntas dan yang sudah tuntas sebanyak 12 siswa $(32,43 \%)$. Berdasarkan data tersebut maka dilakukan tindakan perbaikan melalui Penelitian Tindakan Kelas (PTK) dengan menggunakan metode Think Pair Share (TPS) dalam pembelajaran PKn. Penelitian ini bertujuan untuk mendeskripsikan peningkatan hasil belajar PKn dengan menggunakan metode Think Pair Share (TPS) pada siswa kelas 7 D semester 2 SMP Negeri 1 Japah Kecamatan Japah Kabupaten Blora. Penelitian ini dilakukan dalam 2 siklus dan setiap siklusnya terdiri dari 2 kali pertemuan/tatap muka. Adapun hipotesis tindakannya adalah apabila dalam pembelajaran PKn digunakan metode Think Pair Share (TPS) maka diharapkan hasil belajar siswa meningkat. Indikator keberhasilan tindakan adalah 80 persen dari seluruh siswa mencapai ketuntasan belajar denganKKM e"72. Teknik pengumpulan data digunakan observasi dan tes.Teknik analisis data digunakan teknik deskriptif kualitatif dan kuantitatif.

Hasil penelitian menunjukkan bahwa dengan menggunakan metode Think Pair Share (TPS) dapat meningkatkan hasil belajar PKn pada siswa kelas 7 D SMP N 1 Japah. Peningkatan hasil belajar siswa terjadi pada siklus 1 dan siklus 2 . Pada tahap pra siklus hanya 12 siswa $(32,43 \%)$ yang telah tuntas mencapai KKM, setelah dilakukan tindakan perbaikan melalui metode Think Pair Share (TPS) pada siklus I hasil belajar siswa meningkat menjadi 28 siswa $(75,68 \%)$ yang tuntas mencapai KKM. Pada siklus II tindakan perbaikan lanjut, hasil belajar siswa meningkat lagi menjadi 34 siswa (91,9\%) yang telah tuntas mencapai KKM.
\end{abstract}

Kata kunci: hasil belajar, metode Think Pair Share (TPS)

\section{PENDAHULUAN}

Penggunaan metode ceramah lebih mendominasi selama proses pembelajaran PKn di SMP Negeri 1 Japah Kecamatan Japah Kabupaten Blora, sehingga guru dalam pendekatan pembe- lajaran berorientasi pada dirinya sendiri kurang melibatkan partisipasi/keaktifan siswa. Menurut Jamal Ma'mur Asmani (2012: 32-33) ada beberapa kelemahan dari metode ceramah yaitu: 1) kegiatan pembelajaran menjadi verbalisme (pengertian kata-kata), 2) anak didik yang lebih 
tanggap dari sisi visual akan menjadi rugi dan anak didik yang lebih tanggap auditifnya akan lebih cepat menerimanya, 3) bila terlalu lama akan membosankan, 4) sukar mengontrol sejauh mana perolehan belajar anak didik dan, 5) menyebabkan anak didik pasif.

Berdasarkan hasil pengamatan terhadap pembelajaran PKn di kelas 7D pada materi "Sikap Positif Terhadap Perlindungan dan Penegakan Hak Asasi Manusia", selama proses pembelajaran guru menggunakan metode ceramah sehingga siswa kurang aktif dalam pembelajaran. Hal ini ditunjukkan dari 37 siswa yang berani bertanya ataupun mengemukakan pendapat pada waktu proses pembelajaran berlangsung hanya 7 orang $(18,91 \%)$. Hal ini berpengaruh terhadap pencapaian ketuntasan hasil belajar siswa dengan nilai KKM e" 72 hanya 12 orang $(32,43 \%)$, sedangkan 25 orang $(67,57 \%)$ masih mendapatkan nilai di bawah KKM e" 72.

Untuk mengatasi siswa yang kurang aktif dalam proses pembelajaran yang berdampak pada hasil belajar yang rendah maka dilakukan penelitian tindakan kelas (PTK) dengan menerapkan metode Think Pair Share (TPS) dalam pembelajaran PKn untuk materi selanjutnya yaitu "kemerdekaan mengemukakan pendapat". Metode TPS adalah metode yang memusatkan pada partisipasi/keaktifan siswa dalam pembelajaran melalui bekerja sendiri maupun bekerjasama dengan siswa lain sehingga siswa mampu menguasai atau mendalami materi pembelajaran. Dengan melibatkan siswa secara aktif dalam proses belajar mengajar, metode pembelajaran TPS akan lebih menarik dan tidak monoton dibandingkan metode ceramah. Parameter dalam proses belajar mengajar adalah hasil belajar yang diraih oleh siswa. Dengan pembelajaran TPS perkembangan hasil belajar siswa dapat diidentifikasi secara bertahap, sehingga pada akhir pembelajaran hasil yang diperoleh siswa dapat lebih optimal.

Berdasarkan latar belakang dan identifikasi masalah di atas maka dirumuskan masalah penelitian sebagai berikut: apakah dengan menggunakan metode TPS dapat meningkatkan hasil belajar PKn pada materi "kemerdekaan mengemukakan pendapat" pada siswa kelas 7 D SMP Negeri 1 Japah Kecamatan Japah Kabupaten Blora Semester 2 Tahun Pelajaran 2012/2013?

Adapun tujuan dari penelitian ini adalah untuk mendeskripsikan peningkatan hasil belajar PKn pada materi kemerdekaan mengemukakan pendapat dengan menggunakan metode Think Pair Share pada siswa kelas 7 D SMP Negeri 1 Japah Kecamatan Japah Kabupaten Blora Semester 2 Tahun Pelajaran 2012/2013.

\section{TINJAUAN PUSTAKA}

\section{Hasil Belajar}

Menurut Nana Sudjana (2010:35), hasil belajar adalah suatu akibat dari proses belajar dengan menggunakan alat pengukuran, yaitu berupa tes yang disusun secara terencana, baik tes tertulis, tes lisan maupun tes perbuatan. Sedangkan S. Nasution (1989:18) berpendapat bahwa hasil belajar adalah suatu perubahan pada individu yang belajar, tidak hanya mengenai pengetahuan, tetapi juga membentuk kecakapan dan penghayatan dalam diri pribadi individu yang belajar.

Berdasarkan pendapat para ahli di atas dapat disimpulkan bahwa hasil belajar adalah perubahan perilaku pada individu sebagai akibat dari proses belajar, dapat berupa pengetahuan, sikap maupun keterampilan yang dapat diukur melalui tes tertulis, lisan, maupun perbuatan. Hasil belajar PKn yang dimaksud dalam penelitian ini adalahperubahan/peningkatan pengetahuan/ pemahaman terhadap materi pembelajaran PKn setelah proses pembelajaran dengan metode TPS yang diukur melalui tes tertulis.

\section{Metode Think Pair Share (TPS)}

Metode ini dikembangkan pertama kali oleh Frannk Lyman dari University of Maryland 1989, dengan langkah-langkah pada awal pembelajaran siswa diminta untuk duduk berpasangan, kemudian guru mengajukan satu pertanyaan/masalah kepada siswa. Setiap siswa diminta untuk berpikir sendiri-sendiri terlebih dahulu tentang jawaban atas pertanyaan itu, selanjutnya mendiskusikan 
hasil pemikirannya dengan pasangan disebelahnya untuk memperoleh satu konsensus yang sekiranya dapat mewakili jawaban mereka. Setelah itu, guru meminta setiap pasangan untuk menshare, menjelaskan, atau menjabarkan hasil konsensus atau jawaban yang telah mereka sepakati pada siswasiswa yang lain diruang kelas (Miftahul Huda, 2012: 132).

Agus Suprijono (2011:91) menyatakan bahwa dalam pembelajaran dengan menggunakan metode TPS, guru bertugas untuk membimbing, mengatur, dan mengarahkan siswa agar semua siswa terlibat langsung dan aktif dalam pembelajaran. Dimulai dengan kegiatan "Thinking”, yakni pembelajaran diawali dengan guru mengajukan pertanyaan atau isu terkait dengan pelajaran untuk dipikirkan oleh peserta didik. Guru memberi kesempatan kepada mereka untuk memikirkan jawabannya. Selanjutnya "Pairing", pada tahap ini guru meminta peserta didik berpasang-pasangan dan memberi kesempatan kepada pasangpasangan itu untuk berdiskusi. Melalui diskusi ini dapat memperdalam makna jawaban yang telah dipikirkan melalu inter subjektif dengan pasangannya. Hasil diskusi inter subjektif di tiaptiap pasangan hasilnya dibicarakan dengan pasangan seluruh kelas. Tahap ini dikenal dengan "Sharing". Dalam kegiatan ini diharapkan terjadi tanya jawab yang mendorong pengkonstruksian pengetahuan secara integratif, sehingga peserta didik dapat menemukan struktur dari pengetahuan yang dipelajarinya. Penggunaan metode TPS disamping berdampak pada peningkatan hasil belajar yang berupa penguasaan pengetahuan atau pemahaman materi, juga berdampak pada pembiasaan bagi para siswa untuk berpendapat yang merupakan proses penting masuknya ilmu pengetahuan ke dalam diri siswa.

Selanjutnya Anita Lie (2004:57) menyatakan bahwa TPS adalah salah satu metode pembelajaran yang memberi kesempatan pada siswa untuk bekerja sendiri serta bekerja sama dengan orang lain. Keunggulan metode ini adalah optimalisasi partisipasi siswa.

Berdasarkan berbagai pendapat di atas dapat disimpulkan bahwa metode TPS adalah metode yang memusatkan pada partisipasi siswa dalam pembelajaran melalui bekerja sendiri maupun bekerjasama dengan siswa lain sehingga siswa mampu menguasai atau mendalami materi yang dibahas dan berakibat pada pencapaian hasil belajar yang lebih optimal. Metode pembelajaran ini lebih unggul dibandingkan metode ceramah yang hanya menuntut siswa pasif sehingga siswa kurang mampu menguasai materi dan berakibat pada pencapaian hasil belajar yang kurang baik.

Berdasarkan hasil penelitian terdahulu yang dilakukan Defi Arfina (2012:V) dengan judul "Meningkatkan Keaktifan dan Hasil Belajar Siswa dalam Mata Pelajaran PKn Melalui Metode Pembelajaran Kooperatif Think Pair Share Beserta Pemberian Reward Bagi Siswa Kelas VIII A SMP Islam Sudirman Ambarawa Semester II Tahun Ajaran 2011/2012", disimpulkan bahwa penerapan pembelajaran kooperatif TPS dapat meningkatkan keaktifan dan hasil belajar siswa dalam pembelajaran PKn. Keaktifan siswa meningkat dari Pra Siklus 7,84 persen, Siklus I 67,88 persen, dan Siklus II 75,68 persen dari jumlah siswa 34 orang. Hasil belajar siswa juga meningkat yang ditunjukkan oleh peningkatan nilai rata-rata siswa dari Pra siklus 56,6 dan hanya 38 persen siswa tuntas, Siklus I nilai rata-rata 70,85 dan 73 persen siswa tuntas, kemudian pada Siklus II nilai rata-rata menjadi 75,29 dan 94 persen siswa tuntas. Demikian juga hasil penelitian dari Aswita Ambarwati (2012: xi)yang berjudul" Upaya meningkatkan hasil belajar PKn melalui metode pembelajaran Think-Pair-Share (TPS) mata pelajaran PKn materi makna kedaulatan rakyat pada siswa kelas VIIIa SMP Muhammadiyah 3 Jetis Ponorogo Tahun Pelajaran 2011/ 2012" menyimpulkan bahwa melalui pelaksanaan metode pembelajaran Think-Pair-Share, aktivitas siswa mengalami peningkatan yaitu dari siklus I 71,04 persen dengan kategori cukup meningkat, menjadi 82,7 persen pada siklus II dengan kategori baik, sedangkan aktivitas guru meningkat dari siklus I 70,83 persen dengan kategori cukup, meningkat menjadi 80,25 persen dengan kategori baik pada Siklus II. Nilai hasil belajar siswa pada siklus I dengan nilai rata-rata 73,66 persen dengan 
kategori cukup, meningkat menjadi 85,33 persen dengan kategori baik pada siklus II.

\section{METODE PENELITIAN}

Penelitian ini menggunakan penelitian tindakan kelas (classroom action research). David Hopkins (Trianto, 2012: 15) menyebutkan penelitian tindakan kelas sebagai suatu studi yang sistematis (penelitian) yang dilakukan oleh pelaku pendidikan dalam upaya meningkatkan mutu pembelajaran melalui tindakan yang terencana dan dampak dari tindakan (aksi) yang telah dilakukan.

Model yang digunakan dalam penelitian adalah model penelitian tindakan kelas dari Kemmis dan Mc Taggart dengan menggunakan sistem spiral yang terdiri dari empat tahapan yaitu penyusunan rencana (planning), pelaksanaan tindakan (pra-siklus), setelah siklus 1, dan setelah siklus 2 serta dilihat peningkatannya sesuai indikator keberhasilan.

Indikator keberhasilan adalah harapan terjadinya peningkatan hasil belajar siswa pada akhir siklus 2 yaitu 80 persen dari seluruh siswa kelas 7D SMP N 1 Japah mencapai ketuntasan belajar PKn dengan KKM e"72.

\section{HASIL PENELITIAN}

Tabel 1 berikut ini adalah data rekapitulasi ketuntasan hasil belajar PKn tahap pra siklus, siklus 1 dan siklus 2 pada siswa kelas 7 D SMP N 1 Japah Semester 2/2012-2013.

Berdasarkan tabel 1 diketahui bahwa pada waktu pembelajaran dengan metode ceramah pada pra siklus siswa yang belum tuntas sebanyak 25 siswa $(67,57 \%)$ dan yang sudah tuntas 12 siswa

Tabel 1 Rekapitulasi ketuntasan hasil belajar PKn tahap pra siklus, siklus 1 dan siklus 2

\begin{tabular}{|c|c|c|c|c|c|c|c|c|}
\hline \multirow{2}{*}{ No } & \multirow{2}{*}{$\begin{array}{c}\text { Ketuntasan } \\
\text { Belajar }\end{array}$} & \multirow{2}{*}{ Nilai } & \multicolumn{2}{|c|}{ Pra Siklus } & \multicolumn{2}{|c|}{ Siklus 1} & \multicolumn{2}{|c|}{ Siklus 2} \\
\hline & & & Jml & $\%$ & Jml & $\%$ & $\mathbf{J m l}$ & $\%$ \\
\hline 1 & Tuntas & $\geq 72$ & 12 & 32,43 & 28 & 75,68 & 34 & 91,9 \\
\hline \multirow[t]{5}{*}{2} & Blm Tuntas & $<72$ & 25 & 67,57 & 9 & 24,32 & 3 & 8,10 \\
\hline & Jumlah & & 37 & 100 & 37 & 100 & 37 & 100 \\
\hline & Nilai Rata-rata & & \multicolumn{2}{|c|}{67,45} & \multicolumn{2}{|c|}{75,67} & \multicolumn{2}{|c|}{82,57} \\
\hline & \multicolumn{2}{|l|}{ Nilai Tertinggi } & \multicolumn{2}{|c|}{$\begin{array}{c}95 \text { (1 siswa) atau } \\
2,70 \%\end{array}$} & \multicolumn{2}{|c|}{$\begin{array}{c}95 \text { (4 siswa) atau } \\
10,81 \%\end{array}$} & \multicolumn{2}{|c|}{$\begin{array}{c}95 \text { (5 siswa) atau } \\
13,51 \%\end{array}$} \\
\hline & \multicolumn{2}{|l|}{ Nilai Terendah } & \multicolumn{2}{|c|}{$\begin{array}{c}55 \text { (5 siswa) atau } \\
13,51 \%\end{array}$} & \multicolumn{2}{|c|}{$\begin{array}{c}60(3 \text { siswa }) \text { atau } \\
8,10 \%\end{array}$} & \multicolumn{2}{|c|}{$\begin{array}{c}70 \text { (3 siswa) atau } \\
8,10 \%\end{array}$} \\
\hline
\end{tabular}

tindakan (action), observasi (observation) dan refleksi (reflection). Penelitian ini dilakukan dalam 2 siklus dan setiap siklus terdiri dari 2 kali tatap muka/pertemuan. Subyek penelitian ialah siswa kelas 7D SMP Negeri 1 Japah Kecamatan Japah Kabupaten Blora yang berjumlah 37 siswa. Teknik pengumpulan data menggunakan observasi dan tes dengan instrumen lembar observasi dan soal tes yang telah diuji validitas dan reliabilitasnya. Analisis data menggunakan teknik deskriptif komparatif untuk membandingkan data kuantitatif hasil belajar PKn pada kondisi sebelum
$(32,43 \%)$. Nilai rata-rata kelas adalah 67,45 , dengan nilai tertinggi 95 dan nilai terendah 55.

Setelah dilakukan tindakan perbaikan menggunakan metode pembelajaran Think Pair Share (TPS) pada siklus 1, hasil belajar siswa yang belum tuntas ada 9 siswa $(24,32 \%)$ dan siswa yang sudah tuntas sebanyak 28 siswa $(75,68 \%)$. Nilai rata-rata kelas pada siklus 1 adalah 75,67 , dengan nilai tertinggi 95 dan nilai terendah 60. Jadi pada siklus 1 ini terjadi peningkatan hasil belajar baik ketuntasan belajar, nilai rata-rata maupun nilai terendah yang dicapai oleh siswa dibandingkan 
dengan hasil belajar pada pra siklus. Selanjutnya pada siklus 2 hasil belajar siswa mengalami peningkatan lagi dari siklus 1 baik ketuntasan belajar, nilai rata-rata maupun nilai terendah yang dicapai oleh siswa yaitu sebanyak 34 siswa $(91,9 \%)$ yang sudah tuntas dan 3 siswa $(8,10 \%)$ yang belum tuntas. Nilai rata-rata kelas adalah 82,57, dengan nilai tertinggi 95 dan nilai terendah 70. Rekapitulasi ketuntasan hasil belajar PKn tahap pra siklus, siklus 1 dan siklus 2 dapat digambarkan dalam bentuk diagram sebagai berikut:
Penggunaan metode TPS juga berefek pada pembiasaan bagi para siswa untuk berpendapat yang merupakan proses penting masuknya ilmu pengetahuan ke dalam diri siswa.

Meningkatnya hasil belajar siswa dalam pembelajaran PKn pada penelitian ini juga sejalan dengan hasil penelitian dari Defi Arfina (2012:V), yang menyimpulkan bahwa penerapan pembelajaran kooperatif Think Pair Share dapat meningkatkan keaktifan siswa dan hasil belajar siswa dalam pembelajaran PKn, serta hasil penelitian dari Aswita Ambarwati (2012: xi) yang menyimpulkan bahwa melalui pelaksanaan metode

\section{Diagram 1 Rekapitulasi Hasil Belajar Siswa antara pra siklus, Siklus 1 dan siklus 2}

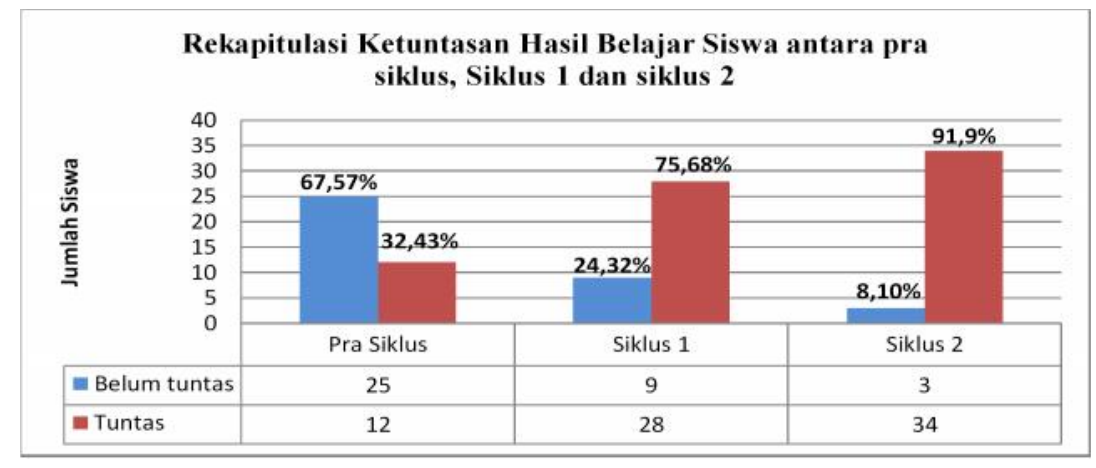

Pembelajaran PKn dengan metode Think Pair Share (TPS) yang telah dilaksanakan dapat meningkatkan hasil belajar siswa. Peningkatan hasil belajar siswa dapat dilihat dari nilai tes siswa yang telah mencapai KKM e"72 pada akhir siklus 2 yang melebihi indikator keberhasilan yang telah ditentukan yaitu 80 persen dari seluruh siswa.

Hasil penelitian yang telah dilakukan menunjukkan adanya peningkatan hasil belajar yang cukup signifikan setelah diterapkannya metode TPS dalam pembelajaran PKn. Sebelum dilaksanakan tindakan pembelajaran, hasil belajar PKn yang ditunjukkan dengan tingkat ketuntasan belajar yang dicapai siswa sebagian besar masih rendah.

Pembelajaran dengan metode TPS lebih mengutamakan partisipasi/keaktifan siswa dalam pembelajaran sehingga siswa mampu menguasai atau mendalami materi yang dibahas dan berakibat pada pencapaian hasil belajar yang lebih optimal. pembelajaran Think-Pair-Share aktivitas siswa, aktivitas guru, dan hasil belajar siswa dalam pembelajaran PKn meningkat dari kategori cukup ke kategori baik.

\section{KESIMPULAN}

Berdasarkan hasil penelitian dan pembahasannya maka dapat disimpulkan bahwa kegiatan pembelajaran dengan menggunakan metode Think Pair Share (TPS) dapat meningkatkan hasil belajar siswa kelas 7 D pada mata pelajaran PKn di SMP Negeri 1 Japah Kabupaten Blora semester genap tahun 2012/2013. Peningkatan hasil belajar tersebut ditunjukkan oleh pencapaian ketuntasan belajar dengan KKM e"72 pada siklus 1 mencapai 75,68 persen dan pada siklus 2 mencapai 91,9 persen dari 37 siswa kelas $7 \mathrm{D}$. 


\section{DAFTAR PUSTAKA}

Agus Suprijono. 2011. Cooperative Learning. Yogyakarta: Pustaka Pelajar.

Anita Lie. 2004. Cooperative Learning (Mempraktekkan Cooperative Learning di RuangRuang Kelas). Jakarta: PT. Grasindo.

Aswita Ambarwati. 2012. Upaya meningkatkan hasil belajar PKn melalui metode pembelajaran Think-Pair-Share (TPS) mata pelajaran PKn materi makna kedaulatan rakyat pada siswa kelas VIIIa SMP Muhammadiyah 3 Jetis Ponorogo Tahun Pelajaran 2011/2012. Skripsi. Ponorogo: FKIP MUHAMMADIYAH.

Defi Arfina. 2012. Meningkatkan Keaktifan dan Hasil Belajar Siswa dalam Mata Pelajaran PKn Melalui Metode Pembelajaran Kooperatif Think Pair Share Beserta Pemberian Reward Bagi Siswa Kelas VIII A SMP Islam Sudirman Ambarawa Semester II Tahun Ajaran 2011/2012. Skripsi. Salatiga: FKIP UKSW.
Jamal Ma'mur Asmani. 2012. 7 Tips Aplikasi Pakem (Pembelajaran Aktif, Kreatif, Efektif dan Menyenangkan). Jogjakarta: Diva press.

Miftahul Huda. 2012. Cooperative Learning (metode, teknik dan model pembelajaran). Yogyakarta: Pustaka Pelajar.

Nana S. 2010. Penilaian Hasil Proses Belajar Mengajar. Bandung: PT Remaja Rasdakarya.

Nasution S.1989. Kurikulum dan Pengajaran. Jakarta: PT Bumi Aksara.

Trianto. 2012. Penelitian Tindakan Kelas. Jakarta: Prestasi Pustaka. 